PRECARIOUS DEMOCRACY 



\section{PRECARIOUS DEMOCRACY}

Ethnographies of Hope, Despair, and Resistance in Brazil

EDITED BY

BENJAMIN JUNGE, SEAN T. MITCHELL, ALVARO JARRÍN, AND LUCIA CANTERO 


\section{Library of Congress Cataloging-in-Publication Data}

Names: Junge, Benjamin, editor. | Mitchell, Sean T., editor. | Jarrín, Alvaro, 1980- editor. | Cantero, Lucia, editor.

Title: Precarious democracy : ethnographies of hope, despair, and resistance in Brazil / edited by Benjamin Junge, Sean T. Mitchell, Alvaro Jarrín, and Lucia Cantero.

Description: New Brunswick : Rutgers University Press, [2021] | Includes bibliographical references and index.

Identifiers: LCCN 2020053254 | ISBN 9781978825666 (cloth) | ISBN 9781978825659 (paperback) | ISBN 9781978825673 (epub) | ISBN 9781978825697 (pdf)

Subjects: LCSH: Social movements—Brazil—History—21st century. | Ethnology—Brazil. | Brazil—Social conditions-1985- | Brazil-Politics and government-2003-

Classification: LCC HN283.5.P734 2021 | DDC $306.0981-\mathrm{dc} 23$

LC record available at https://lccn.loc.gov/2020053254

A British Cataloging-in-Publication record for this book is available from the British Library.

This collection copyright (C) 2021 by Rutgers, The State University of New Jersey

Individual chapters copyright (C) 2021 in the names of their authors

All rights reserved

No part of this book may be reproduced or utilized in any form or by any means, electronic or mechanical, or by any information storage and retrieval system, without written permission from the publisher. Please contact Rutgers University Press, 106 Somerset Street, New Brunswick, NJ 08901. The only exception to this prohibition is "fair use" as defined by U.S. copyright law.

(2) The paper used in this publication meets the requirements of the American National Standard for Information Sciences_-Permanence of Paper for Printed Library Materials, ANSI Z39.48-1992.

www.rutgersuniversitypress.org

Manufactured in the United States of America

References to internet websites (URLs) were accurate at the time of writing. Neither the author nor Rutgers University Press is responsible for URLs that may have expired or changed since the manuscript was prepared. 
For John Burdick (1959-2020), who showed us what collaborative, antiracist, and feminist ethnography looks like, in Brazil and beyond 
